\title{
LISENSI HAK KEKAYAAN INTELEKTUAL (HKI) DALAM PERSPEKTIF HUKUM PERJANJIAN DI INDONESIA
}

\author{
Sulasno \\ Universitas Serang Raya. \\ Email : sulasno1971@gmail.com
}

\begin{abstract}
Licensing is one of several business regulating instruments which enable Intellectual Property Rights (IPR) to be transferable and commercialized. However, it is faced with several issues: (1) What is the arrangement of IPR license agreement in Indonesia like?; (2) How does the law on legal contracts provide IPR-related practitioners with legal protection? The research findings reveal that there has been a complete set of laws in the field of intellectual property in Indonesia which cover Copyrights, Trademark, Patent, Lay-out Design of Integrated Circuit, Industrial Design, Trade Secret, and Protection of Plant Variety. The law regarding legal contracts provides any related parties involved in IPR licensing practices in Indonesia with legal protection by taking in two references: the IPR laws and Book 3 of Code of Laws which are put into a legal contract.
\end{abstract}

Keywords : License, Intellectual Property Rights,

\begin{abstract}
Abstrak
Ada beberapa pengaturan bisnis yang dapat digunakan untuk membawa transfer dan komersialisasi kekayaan intelektual, salah satunya adalah lisensi. Permasalahan sebagai berikut : 1. Bagaimana pengaturan mengenai perjanjian lisensi Hak Kekayaan Intelektual di Indonesia ?; 2. Bagaimana Hukum Perjanjian memberikan perlindungan terhadap para pihak dalam praktek lisensi HKI di Indonesia ? Berdasarkan hasil penelitian dapat disimpulkan : Pengaturan mengenai ketentuan lisensi Hak Kekayaan Intelektual (HKI) di Indonesia diakomodir dalam semua pengaturan perundang-undangan Hak Kekayaan Intelektual meliputi Hak Cipta, Merek, Paten, Desain Tata Letak Sirkuit Terpadu, Desain Industri, Rahasia Dagang dan Perlindungan Varietas Tanaman. Hukum perjanjian memberikan perlindungan terhadap para pihak dalam praktek lisensi HKI di Indonesia dengan melihat pada 2 (dua) pengaturan baik dalam Undangundang HKI itu sendiri dan Buku III Kitab Undang-Undang yang dituangkan dalam suatu perjanjian (kontrak).
\end{abstract}

Kata Kunci : Lisensi, Hak Kekayaan Intelektual, Hukum Perjanjian, Indonesia.

\section{A. PENDAHULUAN}

Meningkatnya era perdagangan di dunia ini makin mempercepat arus penawaran dan pembelian barang dan atau jasa oleh pihak-pihak yang terlibat 
dan ikut serta di dalamnya. Adanya perputaran perdagangan juga makin mengukuhkan bahwa perdagangan antar negara menjadi penting terutama untuk mewujudkan kerjasama internasional.

Kemajuan teknologi informasi dan transportasi yang sangat pesat juga telah mendorong globalisasi Hak Kekayaan Intelektual (HKI) ${ }^{1}$. Barang atau jasa yang hari ini diproduksi oleh suatu negara, di saat berikutnya telah dapat dihadirkan di negara lain. Kehadiran barang atau jasa yang selama proses produksinya telah menggunakan $\mathrm{HKI}^{2}$, dengan demikian juga memerlukan perlindungan HKI atas barang yang bersangkutan. Kebutuhan untuk melindungi barang atau jasa dari kemungkinan pemalsuan atau persaingan yang tidak wajar (curang) juga berarti kebutuhan untuk melindungi HKI yang digunakan pada proses pembuatan produk yang bersangkutan.

Perlindungan Hak Kekayaan Intelektual menjadi penting oleh karena adanya persetujuan Trade Related Aspects of Intellectual Property Rights (TRIPs) yang merupakan salah satu dokumen penting yang dihasilkan dalam Putaran Akhir Uruguay (The Uruguay Final Round) dalam rangka pendirian World Trade Organization (WTO) ${ }^{3}$. TRIPs bertujuan untuk melindungi dan menegakkan hukum Hak Kekayaan Intelektual (HKI) guna mendorong timbulnya inovasi, pengalihan serta penyebaran ilmu pengetahuan, teknologi, seni dan sastra, sehingga bermuara pada kesejahteraan sosial ekonomi masyarakat.

\footnotetext{
${ }^{1}$ Suyud Margono dan Amir Angkasa, 2002, Komersialisasi Aset Intelektual, (Jakarta:Penerbit PT Gramedia Widiasarana Indonesia), 2002, hlm. 2-3.

${ }^{2}$ Sebelum istilah "Hak Kekayaan Intelektual (disingkat HKI) resmi dipergunakan, maka lebih umum dikenal istilah "Hak atas Kekayaan Intelektual" (disingkat HAKI). Namun istilah HAKI sudah tidak dipakai lagi karena berdasarkan Keputusan Menteri Hukum dan Perundang-undangan RI No. M.03.PR.07.10. Tahun 2000, telah ditetapkan secara resmi penggunaan istilah "Hak Kekayaan Intelektual (tanpa kata "atas") atau disingkat HKI. Istilah HKI telah dipergunakan secara resmi dalam Undang-Undang Nomor 14 Tahun 2001 tentang Paten, Undang-Undang No. 15 Tahun 2001 tentang Merek, dan Undang-Undang No.19 Tahun 2002 tentang Hak Cipta. Adapun alasan perubahan istilah tersebut antara lain untuk lebih menyesuaikan dengan kaidah bahasa Indonesia yang tidak menulis kata depan seperti "atas" atau "dari" terutama untuk istilah.

${ }^{3}$ Indonesia merupakan salah satu negara yang telah meratifikasi pembentukkan World Trade Organization (selanjutnya disebut WTO) melalui Undang-Undang No. 7 Tahun 1994. Konsekuensi Indonesia menjadi anggota WTO antara lain, adalah melaksanakan kewajiban untuk menyesuaikan peraturan perundangundangan nasionalnya dengan ketentuan WTO, termasuk yang berkaitan dengan Agreement on Trade Related Aspects of Intellectual Property Rights, dalam Affrilyanna Purba, dkk, 2005, TRIPs-WTO \& Hukum HKI Indonesia, Penerbit PT Rineka Cipta, Jakarta, hlm. 1.
} 
Pertumbuhan ekonomi suatu negara berkembang, termasuk Indonesia, sangat bergantung pada modal asing, dan sistem HKI memegang peranan penting dalam menarik adanya investor asing untuk menanamkan modalnya di Indonesia. Peranannya adalah dengan menciptakan iklim yang kondusif dan aman bagi kegiatan eksploitasi dan komersialisasi HKI asing, termasuk memberikan perlindungan yang memadai terhadap paten, merek terkenal, desain industri, rahasia dagang, hak cipta dan HKI lainnya yang dimiliki oleh investor asing tersebut.

Pengembangan HKI terwujud dalam kebutuhan akan perlindungan hukum yang bertumpu pada pengakuan terhadap hak kekayaan intelektual dan hak untuk atau dalam waktu tertentu mengeksploitasi komersialisasi atau menikmati sendiri kekayaan tersebut. Selama kurun waktu tertentu orang lain hanya dapat menikmati atau menggunakan atau mengeksploitasi hak tersebut atas izin pemilik hak. Karena itu, perlindungan dan pengakuan hak tersebut hanya diberikan khusus kepada orang yang memiliki kekayaan tadi sehingga sering dikatakan bahwa hak seperti itu eksklusif sifatnya.

Terdapat beberapa dari pengaturan bisnis yang mungkin digunakan untuk membawa dari transfer dan komersialisasi HKI. Ada lima jenis utama, menurut Warren $\mathbf{J}$ Keegen dalam Widjaya, bahwa para pengusaha yang bermaksud mengembangkan usahanya secara internasional yaitu :

1. Melalui perdagangan internasional dengan cara ekspor-impor;

2. Dengan pemberian lisensi (licencing);

3. Melakukan franchising (pemberian waralaba);

4. Membentuk perusahaan patungan (joint ventures);

5. Melakukan penana man modal langsung (foreign direct investment) dengan kepemilikan yang menyeluruh, atau melalui merger, konsolidasi maupun akuisisi. ${ }^{4}$

Perlisensian atau lisensi HKI (licencing), pokok bahasan yang selanjutnya akan dikemukakan lebih lanjut dalam tulisan ini, merupakan

${ }^{4}$ Gunawan Widjaya, 2001, Waralaba, Rajawali Press, Jakarta, 2001, hlm.1. 
suatu bentuk pengembangan usaha yang melibatkan pemberian izin atau hak untuk memanfaatkan, menggunakan ataupun melaksanakan hak kekayaan intelektual milik pemberi lisensi meliputi lisensi hak cipta, paten, merek, desain industri, rahasia dagang, desain tata letak sirkuit terpadu dan perlindungan varietas tanaman. Pemberi lisensi sebagai pemilik atau pemegang hak kekayaan intelektual memberikan izin atau hak kepada pihak lain untuk membuat, memproduksi, menjual, memasarkan, mendistribusikan produk berupa barang dan atau jasa yang dihasilkan dengan mempergunakan hak kekayaan intelektual yang dilisensikan tersebut. Dalam bentuknya yang paling sederhana, lisensi diberikan dalam bentuk hak untuk menjual produk barang dan atau jasa dengan mempergunakan HKI yang dilindungi.

Sebagai imbalan dari pembuatan produk dan atau biasanya juga meliputi hak untuk menjual memasarkan dan mendistribusikan produk yang dihasilkan tersebut, pengusaha yang memberi izin, memperoleh pembayaran yang disebut dengan nama royalty. Besarnya royalty ini selalu dikaitkan dengan banyaknya atau besarnya jumlah produk yang dihasilkan dan atau dijual dalam suatu kurun waktu tertentu.

Pemberian lisensi biasanya dituangkan dalam dalam bentuk kontrak ${ }^{5}$ atau perjanjian lisensi. Perjanjian ini dapat memberikan perlindungan para pihak yang berjanji dalam kerangka hukum kontrak (contract law) sehingga dapat mengakomodir kepentingan para pihak dalam suatu kontrak. Hukum kontrak (contract law) atau hukum perjanjian menguasai begitu banyak bagian kehidupan manusia. Kontrak sebagai basis dari transaksi bisnis semakin penting ketika suatu pihak akan menjalin transaksi bisnis dengan pihak lain yang belum dikenal dan baik berada di dalam dan luar negeri.

Pengaturan di bidang perjanjian lisensi telah diatur secara tertulis dalam ketentuan undang-undang hak kekayaan intelektual. Perjanjian lisensi adalah salah satu media yang digunakan oleh para pelaku usaha bidang Hak Kekayaan Intelektual untuk mengembangkan usaha mereka secara internasional. Biasanya bentuk perjanjian lisensi tersebut adalah perjanjian

\footnotetext{
${ }^{5}$ Terminologi kontrak maupun perjanjian mempunyai pengartian yang sama.
} 
baku yang telah dibentuk oleh pihak asing selaku pemberi lisensi. Dalam suatu perjanjian lisensi biasanya memuat ketentuan mengenai para pihak, objek yang dilisensikan, ketentuan teknis, bentuk pengawasan, jangka waktu, wilayah, royalti, pilihan hukum dan ketentuan penutup.

Perjanjian lisensi diwujudkan dalam sistem Hak Kekayaan Intelektual (HKI) dan keberadaan perangkat peraturan perundang-undangan di bidang HKI berikut efektifitas perdagangannya, menjadi tuntutan dalam perdagangan internasional. Perjuangan untuk mewujudkannya, bahkan menjadi agenda penting dalam perundingan Putaran Uruguay atau Uruguay Round yang berlangsung dari 1986 hingga 1994. Perundingan yang melahirkan World Trade Organization atau Organisasi Perdagangan Dunia, antara lain juga menghasilkan Persetujuan tentang Aspek-aspek HKI yang Terkait Dengan Kebijakan Perdagangan atau Trade Related Aspects of Intellectual Property Rights, disingkat TRIPs ${ }^{6}$.

Agreement on Trade Related Aspect of Intellectual Property Rights menekankan sistem HKI dimaksudkan untuk : "contribute to the promotion of technology, to the mutual advantage of producers and users of technological knowledge and in a manner conductive to social and economic welfare, and to a balance of rights and obligations (Art 7). Jadi di samping amanat alih tekhnologi terdapat pula pesan, pembangunan itu juga berdimensi sosial.

Ketentuan dasar pemberian lisensi ada dan diatur dalam semua perundang-undangan mengenai Hak Kekayaan Intelektual. Pengaturan mengenai lisensi ini dimaksudkan untuk memberi landasan pengaturan bagi praktek lisensi yang telah berlangsung juga akan memberikan perlindungan dan kepastian bagi pihak-pihak yang mengadakan perjanjian lisensi dan kepentingan konsumen atau masyarakat yang menggunakan merek barang atau jasa yang diproduksi dan diperdagangkan oleh pemberi dan penerima lisensi.

\footnotetext{
${ }^{6}$ HS. Kartadjoemena, 1996, GATT dan WTO : Sistem, Forum dan Lembaga Internasional di bidang perdagangan, Penerbit UI Press, Jakarta, hlm.98.
} 
Di bidang peraturan perundang-undangan, sampai dengan akhir Maret 2003 Indonesia telah menyelesaikan seluruh perundang-undangan pokok di bidang HKI, yaitu :

1. Undang-undang Nomor 19 Tahun 2002 tentang Hak Cipta (yang menggantikan Undang-undang Nomor 12 tahun 1997 tentang Perubahan Undang-undang Nomor 6 tahun 1981 tentang Hak Cipta sebagaimana telah diubah dengan Undang-undang Nomor 6 Tahun 1987).

2. Undang-undang Nomor 14 Tahun 2001 tentang Paten (yang menggantikan Undang-undang Nomor 13 Tahun 1997 tentang Perubahan Undang-Undang Nomor 6 tahun 1989 tentang Paten).

3. Undang-Undang Nomor 15 Tahun 2001 tentang Merek (yang menggantikan Undang-Undang Nomor 14 Tahun 1997 tentang Perubahan Undang-Undang Nomor 19 Tahun 1992 tentang Merek).

4. Undang-Undang Nomor 30 Tahun 2000 tentang Rahasia Dagang.

5. Undang-Undang Nomor 31 Tahun 2000 tentang Desain Industri.

6. Undang-Undang Nomor 32 Tahun 2000 tentang Desain Tata Letak Sirkuit Terpadu; dan

7. Undang-Undang Nomor 29 Tahun 2000 tentang Perlindungan Varietas Tanaman.

Secara khusus, UU HKI telah mengamanatkan dalam pasalnya untuk mengatur ketentuan lebih lanjut mengenai perjanjian lisensi dengan Peraturan Pemerintah, akan tetapi sampai sekarang PP dimaksud belum disyahkan. ${ }^{7}$ Dalam kaitannya dengan perjanjian lisensi, pemerintah telah menyusun Rancangan Peraturan Pemerintah (RPP) tentang Lisensi, sekalipun telah lama dibuat akan tetapi sampai saat ini RPP tersebut belum disyahkan. Adanya kenyataan tersebut membawa konsekuensi pada kurangnya pengaturan secara formal mengenai Perjanjian Lisensi terutama akan digunakan melengkapi

\footnotetext{
${ }^{7}$ Dalam bidang paten, PP tentang Lisensi dan Lisensi Wajib Paten belum di tetapkan, dalam RPP Lisensi dan Lisensi Wajib Paten sebagai pelaksanaan UU Paten, http : //www. Ristek.go.id, diakses pada tanggal 14 Juli 2011.
} 
perundang-undangan yang terkait untuk melindungi para pihak dalam perjanjian lisensi.

Adanya ketentuan mengenai perjanjian lisensi ini sangat penting dalam upaya pengaturan secara detail dikarenakan dalam pelaksanaannya perjanjian lisensi sendiri merupakan suatu perjanjian yang wajib di daftarkan sehingga banyak kasus mengenai lisensi di pengadilan dan sampai saat ini belum ada aturannya kemudian hukum perjanjianlah yang menyelesaikannya.

Perjanjian lisensi karena melibatkan pihak lokal sebagai licensee / penerima lisensi dan pihak licensor/pemberi lisensi dan terjadi dalam kerangka internasional maka potensi terjadi permasalahan yang menyangkut keseimbangan tawar (bargaining position) para pihak atau perjanjian itu sendiri. Bahkan negara pun mempunyai peran dalam penyelenggaraan perjanjian lisensi yang tidak bertentangan dengan mengancam penyelenggaraan negara dan bertentangan dengan ketentuan perundangundangan. Peran ini tidak hanya sebatas seperti yang di uraikan di atas akan tetapi sampai pada tahap bahwa perjanjian lisensi itu akan dapat membawa rangsangan terhadap pertumbuhan ekonomi Indonesia.

Memang merupakan kerja yang berat, oleh karena itu diperlukan segala sinergi dan upaya dari pihak-pihak yang terlibat dalam perjanjian terutama negara untuk mewujudkan penyelenggaraan perjanjian lisensi yang dapat memberikan perlindungan terhadap para pihak dan terutama terhadap prospek pengembangan di dalam negara Indonesia yang sedang membangun.

Oleh karena begitu pentingnya penjanjian lisensi ini terutama bagi keberlangsungan, perkembangan, pengaturan serta kebutuhan perlindungan hukum perjanjian lisensi dalam HKI di negara Indonesia, maka akan dirumuskan beberapa masalah penting yang akan dibahas, sebagai berikut :

1. Bagaimana pengaturan mengenai perjanjian lisensi Hak Kekayaan Intelektual di Indonesia?

2. Bagaimana Hukum Perjanjian memberikan perlindungan terhadap para pihak dalam praktek lisensi HKI di Indonesia? 


\section{B. PEMBAHASAN}

1. Konsep dasar Perjanjian Lisensi dalam HKI

a. Perjanjian Lisensi sebagai cara dalam komersialisasi HKI.

August, dkk mengatakan : Licensing of intellectual property rights (including patents, trademarks and copyrights, etc) is an increasingly common way to create business opportunities in foreign market.

Menurut August di atas, Lisensi dari hak kekayaan intelektual (termasuk di dalamnya paten, merek dan hak cipta, dan lainnya) adalah sebuah cara biasa guna menambah nilai tambah untuk menciptakan kesempatan bisnis dalam pasar luar negeri. ${ }^{8}$ Selanjutnya, sebuah lisensi adalah suatu kontrak, dan kontrak tersebut menjadi alat pemasaran internasional yang di dalamnya ada izin yang diberikan oleh suatu perusahaan dalam suatu negara kepada perusahaan lain di negara yang berbeda. $^{9}$

Ada beberapa macam alasan bagi suatu bisnis dalam satu negara mempertimbangkan lisensi hak kekayaan intelektual ke perusahaan luar negeri daripada memproduksi langsung produk atau menyediakan jasa di negara tujuan. Kemungkinan transportasi oleh karena jarak yang jauh, atau karena faktor alaminya barang yang bersangkutan sehingga pengiriman melalui laut menjadi tidak bijaksana, atau mungkin budaya dari negara sendiri yang begitu berbeda dengan negara tujuan. Biasanya pasar luar negeri mempunyai hukum nasionalnya sendiri yang membatasi impor barang; melisensikan ke perusahaan luar negeri untuk memproduksi produk dan mengizinkan pemilik untuk mengumpulkan royalti melalui kontrak yang dibuat dengan pihak luar negeri serta mengizinkan untuk mengambil keuntungan di atas merek dagang dan goodwill dari pemilik produk. ${ }^{10}$

\footnotetext{
${ }^{8}$ Ray August, Don Mayer dan Michael Bixny, 2009, International Business Law: Text, Cases, and Practice, Fifth Edition, Pearson Education International, London, hlm. 164.

${ }^{9}$ Ibid

${ }^{10}$ Ibid
} 
Lisensi, hak kekayaan intelektual (HKI) berhubungan dengan nilai ekonomi yang melekat pada karya intelektual dan melekat hak eksklusif bagi pemiliknya. Berdasar hak tersebut, pemilik HKI dapat melaksanakan sendiri atau melarang orang lain melakukan eksploitasi HKI (guna memperoleh nilai materiil) tanpa persetujuan pemiliknya. Komersialisasi HKI merupakan jalan untuk mendapatkan nilai materiil tersebut. Caranya, dapat dilakukan dengan berbagai upaya antara lain melalui penjualan aset (ingat bahwa HKI merupakan aset), lisensi, maupun waralaba. Bagi pemilik HKI, sebelum melakukan komersialisasi sebaiknya memahami hukum perjanjian.

Pasal 1320 Kitab Undang-Undang Hukum Perdata (KUHPerdata) memberikan tuntunan untuk melakukan perjanjian. Menurut pasal tersebut, terdapat 2 (dua) syarat pokok dalam melakukan perjanjian yaitu syarat subyektif dan syarat obyektif. Syarat subyektif menunjuk adanya kesepakatan bagi para pihak untuk mengikatkan diri, artinya dalam suatu perjanjian tidak diperkenankan adanya unsur paksaan, penipuan maupun kekhilafan. Persyaratan subyektif lainnya adalah adanya kecakapan para pihak untuk melakukan perjanjian. Artinya, para pihak telah dewasa serta tidak di bawah pengampuan/perwalian sedangkan mengenai obyek yang diperjanjikan sebagai syarat obyektif meliputi adanya suatu hal tertentu dan suatu sebab yang halal. Syarat adanya suatu hal tertentu adalah bahwa suatu perjanjian mempunyai obyek yang ditentukan berupa benda yang ada maupun yang akan ada (Pasal 1332-1335 KUHPerdata) sedangkan persyaratan adanya suatu sebab yang halal adalah berkaitan dengan kesusilaan, ketertiban umum dan tidak bertentangan dengan undangundang (Pasal 1337 KUHPerdata).

Guna memperoleh keuntungan yang lebih banyak, Pemilik HKI dapat memberikan lisensi kepada lebih dari satu pihak kecuali diperjanjikan. Artinya, apabila telah diperjanjikan bahwa pemilik HKI tidak akan memberikan lisensi berikutnya kepada pihak lain, maka ia 
harus mematuhi perjanjian tersebut. Di Indonesia, perjanjian lisensi di bidang HKI, prinsip dasar yang paling utama adalah tidak bertentangan dengan kepentingan ekonomi Indonesia dan dilarang memuat ketentuan pembatasan-pembatasan yang menghambat kemampuan bangsa Indonesia dalam menguasai dan mengembangkan teknologi. Prinsip ini dimaksudkan untuk merangsang pertumbuhan ekonomi Indonesia dalam arti meningkatkan taraf hidup dan kualitas kehidupan rakyat Indonesia.

b. Pengertian dan Persyaratan Perjanjian Lisensi.

Dalam hukum asing dijumpai istilah overeenkomst (bahasa Belanda), contract /agreement (bahasa Inggris), dan sebagainya yang merupakan istilah yang dalam hukum kita dikenal sebagai "kontrak" atau "perjanjian". Umumnya dikatakan bahwa istilah-istilah tersebut memiliki pengertian yang sama, sehingga tidak mengherankan apabila istilah tersebut digunakan secara bergantian untuk menyebut sesuatu konstruksi hukum.

Sehubungan dengan hal tersebut maka akan lebih jelas apabila melihat kepada rumusan atau pengertian yang diberikan oleh Subekti ${ }^{11}$, bahwa kontrak adalah lebih sempit daripada perjanjian, karena ditujukan kepada perjanjian atau persetujuan tertulis. Menurut Black's Dictionary juga dikatakan lebih luas daripada kontrak. ${ }^{12}$

Memang dari pemakaian sehari-hari pun apabila diperhatikan, maka kontrak yang dilakukan oleh seseorang biasanya dilakukan secara tertulis. Dengan demikian, maka tampak bahwa yang dimaksudkan dengan dengan kata kontrak adalah perjanjian tertulis, dan bahkan lebih menjurus kepada pembuatan suatu akta.

\footnotetext{
${ }^{11}$ Subekti, 1990, Hukum Perjanjian, PT.Intermasa, Jakarta, hlm.1.

${ }^{12}$ Henry Campbell Black, 1990, Black's Law Dictionary, West Publishing Co, ST.Paul.Minn 1990, hlm.67.
} 
Pada pasal 1313 KUHP merumuskan pengertian perjanjian, adalah : suatu perbuatan satu orang atau lebih mengikatkan dirinya terhadap satu orang atau lebih.

Namun para ahli hukum mempunyai pendapat yang berbedabeda mengenai pengertian perjanjian, Abdulkadir Muhammad mengemukakan bahwa perjanjian adalah suatu persetujuan dengan mana dua orang atau lebih saling mengikatkan diri untuk melaksanakan suatu hal dalam lapangan harta kekayaan. ${ }^{13}$ Ahli hukum lain mengemukakan bahwa suatu perjanjian adalah suatu peristiwa dimana seorang berjanji kepada seseorang yang lain atau dimana dua orang itu saling berjanji untuk melaksanakan suatu hal yang menimbulkan perikatan berupa suatu rangkaian perkataan yang mengandung janjijanji atau kesanggupan yang diucapkan atau ditulis. Menurut J.Satrio perjanjian dapat mempunyai dua arti, yaitu arti luas dan arti sempit, dalam arti luas suatu perjanjian berarti setiap perjanjian yang menimbulkan akibat hukum sebagai yang dikehendaki oleh para pihak termasuk didalamnya perkawinan, perjanjian kawin, dll, dan dalam arti sempit perjanjian disini berarti hanya ditujukan kepada hubunganhubungan hukum dalam lapangan hukum kekayaan saja, seperti yang dimaksud oleh buku III Kitab Undang-undang Hukum Perdata.

Dari segi bahasa, perlisensian berakar dari kata dasar lisensi. Kata tersebut berasal dari bahasa asing license yang dalam bahasa Indonesia berarti surat ijin. Pengertian yang terkandung di dalamnya berpangkal semuanya pada ijin tadi, walaupun penggunaannya dapat berbeda tergantung dari tujuan dan sumber yang memberi ijin. White ${ }^{14}$ menyajikan pengertian : A license is the granting permission of rights to make, use / or sell a certain product, design, or process or to perform certain other actions, the granting being done by a party who has the rights to do so.

\footnotetext{
${ }^{13}$ Abdul Kadir Muhammad, 1992, Hukum Perikatan, PT.Citra Aditya Bakti, Bandung, hlm.78

${ }^{14}$ Edward P White, 1990, Licencing :A Strategy for Profits, KEW Licensing, Chaper Hill, NC, hlm. 5.
} 
Dalam kaitannya dengan HKI, Mc Keough dan Stewart mengatakannya sebagai : bundles of rights which the law accords for the protection of creative efforts or more especially for the protection of economic investment in creative effort. ${ }^{15}$

Pengertian-pengertian di atas memiliki unsur yang sama, yaitu pemberian ijin kepada orang atau badan hukum, diberikan pihak yang memiliki kewenangan atau hak, untuk melakukan sesuatu yang tertentu dengan hak tersebut, dan penggunaannya terikat pada syarat tertentu. Ijin penggunaan hak itulah yang menjadi ciri pokok, dan membedakan lisensi dari berbagai bentuk dan jenis hubungan lainnya. Dengan pengertian tadi, perlisensian berarti ikhwal dan kegiatan pemberian dan perolehan lisensi.

Dalam sistem hukum sipil (civil law system), lisensi sebagai suatu bentuk perjanjian pada dasarnya tidak dikenal. ${ }^{16}$ KUHPerdata tidak mengenal lisensi ke dalam bentuk perjanjian, dikarenakan lisensi adalah lembaga hukum asing yang berasal dari sistem hukum lain yang masuk ke dalam sistem tata hukum Indonesia.

Baru dalam perkembangan akhir-akhir ini sesuai dengan perkembangan masyarakat, lisensi sebagai bentuk perjanjian dikenal diluar dari yang ada dalam Kitab Undang-undang Hukum Perdata. Sebagai suatu bentuk perjanjian, lisensi masuk ke dalam sistem tata hukum Indonesia melalui 2 (dua) macam cara yakni (a). melalui proses legislatif atau melalui proses pembentukan undang-undang oleh DPR dan (b). melalui yurisprudensi ataupun melalui praktik.

Seperti halnya perjanjian pada umumnya, perlisensian juga merupakan peristiwa hukum. Persetujuan pemberian lisensi dan dengan demikian merupakan penerima lisensi, dengan segala hak dan kewajiban yang disepakati keduanya, adalah peristiwa hukum.

\footnotetext{
${ }^{15}$ Jill McKeough dan Andrew Stewart, 1997, Intellectual Property in Australia, Butterworths, Australia, hlm.1

${ }^{16}$ Badan Pembinaan Hukum Nasional, 2006, Laporan Akhir tentang Kompilasi Bidang Hukum Perjanjian Lisensi, BPHN, Jakarta, hlm.10.
} 
Perlisensian karenanya adalah perjanjian, dan terhadapnya berlaku pula ketentuan hukum perjanjian.

Dalam literatur lain mengatakan bahwa perjanjian lisensi adalah perjanjian antara dua pihak atau lebih, yang mana salah satu pihak yaitu pemegang hak bertindak sebagai pihak yang memberikan lisensi, sedangkan pihak yang lain bertindak sebagai pihak yang menerima lisensi. Pengertian lisensi itu sendiri adalah izin untuk menikmati manfaat ekonomi dari suatu objek yang dilindungi HKI untuk jangka waktu tertentu. ${ }^{17}$

Perjanjian lisensi harus ditulis secara tertulis dan harus ditandatangani oleh kedua pihak. Perjanjian lisensi sekurang-kurangnya memuat informasi tentang :

a) Tanggal, bulan dan tahun tempat dibuatnya perjanjian lisensi;

b) Nama dan alamat lengkap serta tandatangan para pihak yang mengadakan perjanjian lisensi;

c) Objek perjanjian lisensi;

d) Jangka waktu perjanjian lisensi;

e) Dapat atau tidaknya jangka waktu diperpanjang;

f) Pelaksanaan lisensi untuk seluruh atau sebagian dari hak eksklusif;

g) Jumlah royalti dan pembayarannya;

h) Dapat atau tidaknya penerima lisensi memberikan lisensi lebih lanjut kepada pihak ketiga;

i) Batas wilayah berlakunya perjanjian lisensi, apabila diperjanjikan; dan

j) Dapat atau tidaknya pemberi lisensi melaksanakan sendiri karya yang telah dilisensikan.

c. Jenis-jenis Perjanjian Lisensi.

\footnotetext{
${ }^{17}$ Andi Fahmi Lubis, dkk, 2009, Hukum Persaingan Usaha Antara Teks \& Konteks, Penerbit GTZ GmbH, Jerman, hlm. 239.
} 
Mengingat hak ekonomis yang terkandung dalam setiap hak eksklusif adalah banyak macamnya, maka perjanjian lisensi pun dapat memiliki banyak variasi.

Terdapat jenis-jenis perlisensian yang dibedakan dalam beberapa kelompok berdasarkan objek, sifat, lingkup, dan cara terjadinya perlisensian. Menurut Lee dan Davidson ${ }^{18}$, membedakan dalam 2 (dua) jenis lisensi yaitu Exclusive dan Non Exclusive licenses, sedangkan Dratler ${ }^{19}$ membedakan cara terjadinya perlisensian, yaitu :

1. Voluntary Licenses, yaitu perlisensian yang terjadi berdasarkan prakarsa dan karena adanya kesepakatan pihak-pihak pemberi dan penerima lisensi;

2. Non Voluntary licenses, yaitu perlisensian yang terjadi karena adanya permintaan pihak yang memerlukan lisensi dan diajukan kepada, disetujui dan diberikan oleh pihak yang berwenang yang ditetapkan oleh dan dengan syarat serta tata cara yang ditetapkan dalam undang-undang.

Sesuai dengan namanya, perlisensian ini memang berlangsung tanpa kesukarelaan pemilik hak. Non Voluntary licences seringkali disebut Compulsory licenses, ada pula yang menyebut In-voluntary licences. Dalam bahasa Indonesia, padanan kata yang diberikan adalah lisensi wajib atau perlisensian wajib. Lisensi wajib adalah lisensi yang oleh peraturan perundang-undangan atau oleh pemerintah diwajibkan untuk diberikan oleh pemilik HKI kepada pihak lain atas pertimbangan tertentu. Lisensi sukarela adalah lisensi yang diberikan oleh pemilik HKI kepada pihak lain secara sukarela tanpa harus dengan suatu ketentuan yang memaksa.

Lisensi ekslusif digunakan bila pemilik HKI mengalihkan satu atau beberapa hak dari suatu ciptaan atau temuan yang dimilikinya kepada

\footnotetext{
${ }^{18}$ Lewis C Lee dan Scott Davidson, 1990, Introduction to Intellectual Property Law, Butterworth, London, hlm. 77.

${ }^{19}$ Jay Dratler Jr, 1994, Intellectual Property Rights : Commercial, Creative, and Industrial Property, Law Journal Seminars-Press, hlm.67.
} 
pihak penerima hak, tetapi tetap dengan menahan hak-hak lain yang masih ada pada HKI tersebut. Lisensi non eksklusif adalah satu bentuk pemberian hak berupa hak eksploitasi satu atau beberapa hak yang dimiliki seorang pemilik HKI. Walaupun pemilik telah memberikan suatu lisensi yang tidak eksklusif kepada pemegang hak, pemilik HKI tidak tertutup kemungkinannya untuk memberikan hak serupa kepada orang lain pada waktu bersamaan.

Perjanjian lisensi dapat dibuat secara khusus, misalnya tidak bersifat eksklusif. Apabila dimaksudkan demikian, maka hal tersebut harus secara tegas dinyatakan dalam perjanjian lisensi. Jika tidak maka perjanjian lisensi dianggap tidak memakai syarat non eksklusif. Oleh karenanya pemegang hak atau pemberi lisensi pada dasarnya masih boleh melaksanakan sendiri apa yang dilisensikannya atau member lisensi yang sama kepada pihak yang lain. $^{20}$

2. Pengaturan Lisensi dalam perundang-undangan HKI.

Di negara Indonesia, Pengaturan mengenai Hak Kekayaan intelektual merupakan standar minimal berasaskan national treatment sebagai akibat dari bergabungnya negara Indonesia dalam Organisasi Perdagangan Dunia atau WTO.

Sesuai dengan ketentuan dalam paket Undang-Undang tentang HKI, maka suatu perjanjian lisensi wajib dicatatkan pada Direktorat Jenderal Hak Kekayaan Intelektual yang kemudian dimuat dalam Daftar Umum dengan membayar biaya yang besarnya ditetapkan dengan Keputusan Menteri. Namun, jika perjanjian lisensi tidak dicatatkan, maka perjanjian lisensi tidak mempunyai akibat hukum terhadap pihak ketiga. Adapun, ketentuan mengenai lisensi meliputi keseluruhan perundangundangan HKI yang terdiri dari :

a. Bidang Paten, di bidang paten, pengaturan mengenai Lisensi terdapat dalam Bab V bagian kedua pasal 69 sampai pasal 87 Undang-undang

\footnotetext{
${ }^{20}$ Andi Fahmi Lubis, Op. Cit, hlm. 240.
} 
Nomor 14 Tahun 2001 tentang Paten (diundangkan 1 Agustus 2001, Lembaran Negara Nomor 109, Tambahan Lembaran Negara Nomor 4130).

Pemerintah pun telah membuat Rancangan Peraturan Pemerintah (RPP) yang semula PP tentang Lisensi diubah menjadi PP tentang Perjanjian Lisensi dan Lisensi Wajib Paten.

b. Bidang Merek, di bidang Merek, pengaturan mengenai Lisensi terdapat dalam Bab I Ketentuan umum, Pasal 1 angka 14 Undang-undang Nomor 15 Tahun 2001, atau disingkat UU Merek 2001 (diundangkan 1 Agustus 2001, Lembaran Negara Nomor 110 , Tambahan Lembaran Negara Nomor 4131).

Menurut Pasal 1 angka 14, Lisensi adalah izin yang diberikan oleh pemilik Merek terdaftar kepada pihak lain melalui suatu perjanjian berdasarkan pada pemberian hak (bukan pengalihan hak) untuk menggunakan Merek tersebut, baik untuk seluruh atau sebagian jenis barang dan/atau jasa yang didaftarkan dalam jangka waktu dan syarat tertentu.

Selain itu dalam pasal 43 sampai dengan pasal 49 Bagian Kedua mengenai Lisensi yang terdapat dalam Bab V Pengalihan Hak atas Merek Terdaftar.

c. Bidang Varietas Tanaman, di bidang Perlindungan Varietas Tanaman, pengaturan mengenai Lisensi diatur dalam bab V bagian kedua pasal 42 sampai dengan pasal 55 Undang-undang Nomor 29 Tahun 2000 atau disingkat UU PVT 2000 (diundangkan 20 Desember 2000, Lembaran Negara Nomor 241, Tambahan Lembaran Negara Nomor 4043).

d. Bidang Hak Cipta, Pengaturan Lisensi dalam Undang-Undang Nomor 19 Tahun 2002 tentang Hak Cipta, atau disingkat UUHC 2002 (diundangkan 29 Juli 2002, Lembaran Negara Nomor 85, Tambahan Lembaran Negara Nomor 4220) terdapat dalambab V pasal 45 sampai dengan pasal 47 mengenai Lisensi. 
e. Bidang Rahasia Dagang, di bidang Rahasia Dagang, pengaturan Lisensi terdapat dalam Bab IV bagian kedua pasal 6 sampai dengan pasal 9 Undang-Undang Nomor 30 Tahun 2000 mengenai Rahasia Dagang (diundangkan pada tanggal 20 Desember 2000, lembaran negara RI tahun 2000 Nomor 242.

f. Bidang Desain Industri, pengaturan Lisensi terdapat dalam Bab V bagian pertama pasal 31 sampai dengan pasal 36 Undang-Undang Nomor 31 Tahun 2000 mengenai Desain Industri (diundangkan pada tanggal 20 Desember 2000, lembaran negara RI tahun 2000 Nomor 243.

g. Bidang Desain Tata Letak Sirkuit Terpadu, pengaturan Lisensi terdapat dalam Bab V bagian pertama pasal 25 sampai dengan pasal 28 UndangUndang Nomor 32 Tahun 2000 mengenai Desain Tata Letak Sirkuit Terpadu (diundangkan pada tanggal 20 Desember 2000, lembaran negara RI tahun 2000 Nomor 244.

3. Perlindungan Hukum Perjanjian atas praktek Lisensi Hak Kekayaan Intelektual

Pada dasarnya, para pihak dalam melakukan suatu perjanjian berdasar pada asas konsensual, asas kebebasan berkontrak dan asas pacta sunt servanda sebagaimana dinyatakan dalam buku III bagian ketiga pasal 1338 KUHPerdata, berbunyi : "Semua ${ }^{21}$ perjanjian yang dibuat secara $\mathrm{sah}^{22}$ berlaku sebagai undang-undang ${ }^{23}$ bagi mereka yang membuatnya" ${ }^{24}$

Pasal 1320 KUHPerdata pun menyatakan bahwa untuk sahnya perjanjian-perjanjian diperlukan empat syarat :

\footnotetext{
${ }^{21}$ Dengan istilah "semua" terkandung suatu asas yang dikenal dengan asas partij outonomie atau asas kebebasan berkontrak.

${ }^{22}$ Dengan istilah secara "sah", pembentuk undang-undang hendak menunjukkan bahwa pembuatan perjanjian harus menurut hukum. Semua perjanjian yang dibuat menurut hukum atau secara sah adalah mengikat. Sah disini bahwa perbuatan perjanjian harus mengikuti apa yang ditentukna opelh pasal 1320 KUHPerdata.

${ }^{23}$ Undang-undang menentukan bahwa perjanjian yang sah berkekuatan sebagai undang-undang. Semua perjanjian yang dibuat secara sah berlaku sebagai undang-undang bagi mereka yang membuatnya. Perjanjianperjanjian itu tidak dapat ditarik kembali, selain kesepakatan kedua belah pihak atau karena alasan-alasan yang oleh undang-undang dinyatakan cukup untuk itu. Perjanjian itu harus dilaksanakan dengan itikad baik.

${ }^{24}$ R.Subekti dan R.Tjitrosudibio, 1992, Kitab Undang-undang Hukum Perdata, Pradnya Paramita, Jakarta, hlm. 285.
} 
1. Sepakat mereka yang mengikatkan dirinya;

2. Kecakapan untuk membuat suatu perikatan;

3. Suatu hal tertentu;

4. Suatu sebab yang halal; ${ }^{25}$

Secara teorikal hukum perjanjian, membuat suatu perjanjian berdasar pada syarat sahnya perjanjian dan asas-asas yang melekat dalam hukum perjanjian. Akan tetapi, dikarenakan keadaan sosial ekonomi maka ditentukanlah syarat-syarat secara sepihak. Pada umumnya pihak lawannya (wederpartij) mempunyai kedudukan (ekonomi) lemah baik karena posisinya, maupun karena ketidaktahuannya hanya menerima apa yang disodorkan.

Melihat pada ciri-ciri di atas tersebut, maka lisensi yang dituangkan dalam perjanjian mempunyai bentuk perjanjian baku atau standart contract yang dibuat oleh licensor. Dengan penggunaan perjanjian baku ini, maka pengusaha akan memperoleh efisiensi dalam pengeluaran biaya, tenaga dan waktu. ${ }^{26}$

Akan tetapi dikarenakan secara khusus jenis perjanjian terkait dengan lisensi Hak Kekayaan Intelektual maka mengikuti pengaturan yang ada dalam lingkup Hak Kekayaan Intelektual seperti ada dalam beberapa pasal yang di uraikan di atas terkait dengan bidang hak kekayaan intelektual.

Dalam pelaksanaannya hal yang paling penting dalam lisensi adalah menentukan isi perjanjian lisensi. Karena bunyi ketentuan yang disepakati akan sangat menentukan bagi pemegang HKI dan pemegang lisensi. Suatu norma hukum perjanjian yang baik harus memuat rumusan pasal yang pasti (lex certa), jelas (concise) dan tidak membingungkan (unambiguous). ${ }^{27}$

\footnotetext{
${ }^{25}$ Mariam Darus Badrulzaman, 1994, Aneka Hukum Bisnis, Alumni, Bandung, hlm.23.

${ }^{26}$ Ibid, hal 46

${ }^{27}$ Ika Riswanti Putranti, 2010, Lisensi Copyleft dan Perlindungan Open Source Software di Indonesia, Gallery Ilmu, Yogyakarta, hlm. 107.
} 
Dalam lisensi HKI, baik dalam bidang hak cipta, merek, paten, rahasia dagang, desain industri, desain tata letak sirkuit terpadu dan perlindungan varietas tanaman semuanya berdasar pada ketentuan yang ada dalam pasal-pasal yang mengatur mengenai perjanjian lisensi.

Berikut ini dikemukakan beberapa kasus yang terjadi di pengadilan niaga yang berkenaan dengan perjanjian lisensi HKI, sebagai berikut :

a. Kasus perjanjian lisensi Cap Kaki Tiga (Merek)

Kasus ini bermula dari gugatan yang diajukan PT Sinde yang diajukan Oktober 2008. Gugatan dilayangkan lantaran Wen Ken telah menghentikan perjanjian lisensi secara sepihak terhitung 7 Februari 2008 dan berniat mengalihkan lisensi merek Cap Kaki Tiga ke pihak lain. PT Sinde Budi menilai pengakhiran itu tidak sah.

Dalil itu mengacu pada Pasal 1338 KUHPerdata, dimana perikatan dapat dibatalkan atas kesepakatan kedua belah pihak. Lalu Pasal 1266 KUHPerdata menentukan pembatalan perjanjian secara sepihak harus diajukan ke pengadilan. PT Sinde Budi menilai penghentian itu merupakan perbuatan melawan hukum.

Akibat pembatalan perjanjian itu, Sinde Budi mengklaim mengalami kerugian sebesar Rp200 miliar sebagai kompensasi biaya promosi yang telah dikeluarkan. Dengan pengakhiran sepihak itu promosi produk Cap Kaki Tiga menjadi sia-sia dan tidak bernilai lagi.

Selain itu, Sinde Budi mengalami kerugian bisnis berupa potensi kerugian pendapatan (loss profit) sebesar 5 persen dari total omset per tahun selama 10 tahun, yaitu Rp200 miliar. Termasuk pula kerugian investasi berupa alat produksi, tanah dan bangunan yang berjumlah Rp200 miliar. Kerugian immateriil juga diperhitungkan sebesar Rp200 miliar. Sehingga total seluruh ganti rugi sebesar Rp800 miliar. ${ }^{28}$

Dalam putusannya, Majelis hakim Pengadilan Negeri Bekasi mengakui keabsahan perjanjian lisensi Cap Kaki Tiga. Namun soal

\footnotetext{
28“"Perjanjian Lisensi Cap Kaki Tiga Tetap Sah”, http://www.hukumonline.com, diakses pada tanggal 20 Juli 2011.
} 
penghentian perjanjian lisensi sepihak, bukan kewenangan pengadilan itu melainkan Pengadilan Niaga Jakarta Pusat.

Di Pengadilan Niaga, Gugatan ini kandas lantaran Pengadilan Niaga Jakarta Pusat menyatakan tidak berwenang memeriksa dan mengadili perkara ini. Pasalnya, materi gugatan PT Tiga Sinar Mestika, perusahaan yang mendapat kuasa subsitusi dari Wen Ken, tidak masuk dalam kompetensi Pengadilan Niaga. Majelis hakim menilai pokok permasalahan gugatan adalah wanprestasi bukan lisensi merek. Penggugat mengakui adanya kerja sama sehingga jika ada yang tidak dipenuhi berarti wanprestasi, karena tergolong sebagai perkara perdata biasa, majelis menyatakan gugatan seharusnya diperiksa dan diadili oleh pengadilan negeri.

b. Perjanjian lisensi di bawah tangan atas karya seni lukisan Affandi (Hak Cipta)

Bahwa perjanjian lisensi yang berdasarkan akta di bawah tangan berlaku sah dan mengikat pihak ketiga selama perjanjian itu dibuat sesuai dengan peraturan perundang-undangan yang berlaku. Perlindungan hukum bagi penerima lisensi dapat diberikan berdasarkan Undang-undang dan dari isi perjanjian lisensi yang dibuat berdasarkan azas kebebasan berkontrak. Perlindungan Hukum bagi ahli waris hak cipta adalah ahli waris dapat menuntut agar nama pencipta tetap dicantumkan dalam ciptaan, ciptaan tidak boleh diubah tanpa persetujuan, dan ahli waris berhak untuk mencabut perjanjian lisensi yang telah dilakukan antara pencipta dengan pihak ketiga. ${ }^{29}$

c. Perjanjian lisensi importasi paralel (Hak Paten)

Importasi paralel adalah impor produk obat (yang dilindungi paten di dalam negeri) yang lebih murah oleh pihak lain, karena perbedaan harga yang ditetapkan oleh pemegang paten di setiap negara yang berbeda. Penggunaan paten oleh Pemerintah penggunaan obyek paten

\footnotetext{
${ }^{29}$ Juwita Aria Kasih, 2009, Perjanjian Lisensi terhadap Seluruh Karya Seni Berdasarkan Akta di Bawah Tangan Studi Kasus terhadap Perjanjian Lisensi Karya Seni Affandi, Thesis, Fakultas Hukum Universitas Gadjah Mada, hlm. 1.
} 
oleh pemerintah (lisensi wajib; importasi paralel) ketika terjadi keadaan darurat, seperti bencana alam dan epidemi penyakit.

Importasi Paralel, menurut UU Paten kegiatan mengimpor produk farmasi yang dilindungi oleh paten di Indonesia bukan tindakan pidana atau kriminal, tetapi pelaku impor paralel bisa digugat secara perdata oleh pemilik paten di Indonesia, melalui pengadilan niaga. Sehingga memiliki keterbatasan untuk dilaksanakan.

Lisensi wajib tercantum dalam UU paten, namun sejauh ini belum bisa dilaksanakan karena belum ada peraturan pemerintah yang mengatur ketentuan ini. Penggunaan obyek paten oleh pemerintah (lisensi wajib; importasi paralel) ketika terjadi keadaan darurat, seperti bencana alam dan epidemi penyakit. ${ }^{30}$

d. Perjanjian lisensi atas desain industri

Gugatan pembatalan pendaftaran Desain Industri didasarkan kepada Pasal 38 ayat (1) Undang-Undang No. 31 Tahun 2000 tentang Desain Industri terhadap desain industri Daftar No. ID 0008 028-D dengan judul "TIP REFIL BALLPOINT". Alasan pembatalan adalah bahwa Desain industri “TIP REFIL BALLPOINT” atas nama Tergugat adalah telah tidak baru lagi pada tanggal penerimaan permohonan pendaftarannya.

Dalam putusan Mahkamah Agung menyatakan desain industri Daftar No. ID 0008 028-D dengan judul “TIP REFIL BALLPOINT" atas nama Tergugat adalah tidak baru; Menyatakan batal atau setidaktidaknya membatalkan pendaftaran desain industri Daftar No. ID 0008 028-D dengan judul "TIP REFIL BALLPOINT" atas nama Tergugat dari Daftar Umum Desain Industri dengan segala akibat hukumnya. ${ }^{31}$

e. Perjanjian lisensi rahasia dagang

\footnotetext{
${ }^{30}$ Lutfiyah Hanim, "Akses atas ARV dan Perlindungan HKI", http://www.jothi.or.id, diakses pada tanggal 20 Juli 2011.

${ }^{31}$ Direktori Putusan Mahkamah Agung Republik Indonesia, http://www.putusan.mahkamah agung.go.id, diakses pada tanggal 20 Juli 2011, hlm. 4.
} 
PT Basuki Pratama Engineering ( berdiri sejak, 1981), mengajukan gugatan ganti rugi melalui Pengadilan Negeri Bekasi terhadap PT Hitachi Constructuin Machinery Indonesia sekitar Rp127 miliar, karena diduga melanggar rahasia dagang.

PT BPE bergerak dalam bidang produksi mesin-mesin industri, dengan produksi awal mesin pengering kayu.Mantan karyawannya (Calvin, Faozan, A. Saangka) yg pindah bekerja di PT. Hitachi dituduh telah mencuri rahasia dagang berupa metode produksi dan metode penjualan mesin boiler.

Kuasa Hukum PT. Hitachi mendalilkan bahwa PN. Bekasi tidak berwenang mengadili kasus tsb karena sengketa HaKI mestinya ditangani Pengadilan Niaga. Pada awal tahun 2009, PN Bekasi dalam putusan sela, tdk dpt menerima gugatan ganti rugi karena sengketa HaKI ditangani oleh Pengadilan Niaga.

f. Perjanjian lisensi Desain Tata Letak Sirkuit terpadu

Perusahaan NVIDIA memproduksi produk-produk berkualitas dengan merek yang sudah terkenal yaitu GeForce. Perusahaan NVIDIA sudah mendaftarakan terlebih dahulu desain tata letak sirkuit terpadu untuk produk mereka. Sebuah perusahaan menengah AMD/ATI bergerak di bidang yang sama dengan NVIDIA. Tanpa sepengetahuan perusahaan NVDIA, perusahaan MD meniru desain tata letak sirkuit terpadu milik NVDIA. Setelah NVDIA tahu dan diadakan penyelidikan, terjadilah negosiasi dengan perusahaan AMD bahwa AMD harus membagi keuntungan sebesar 30\% dari hasil penjualannya.

g. Perjanjian lisensi Perlindungan Varietas Tanaman

Petani Kabupaten Nganjuk yang bernama Pak Tukirian,dituduh mencuri benih induk oleh perusahaan produsen benih jagung hybrida, PT. BISI, anak perusahaan Charoen Pokphand. Konglomerasi usaha input pertanian terbesar di Asia tersebut, juga menuduh Pak Tukirin melakukan sertifikasi liar atas benih jagung yang mereka patenkan. 
Pak Tukirin melakuan inovasi atas cara berbudidaya jagung dengan melakukan penyerbukan silang antar tanaman jagung. Seperti diketahui, jagung memiliki kemampuan melakukan perkawinan sendiri karena pada satu batang jagung terdapat alat reproduksi jantan dan betina. Yang dilakukan pada Tukirin adalah menanam benih jagung BISI yang dibelinya dalam 4 jalur. Ketika jagung-jagung tersebut 3 bulan, dan mulai mengeluarkan serbuk sari, maka 3 jalur jagung dipotong serbuk sarinya. Dia sebut jalur ini jagung betina. Satu jalur jagung tetap dibiarkan serbuk sarinya berkembang, jalur ini dia sebut jagung jantan. Dengan pengaturan ini, maka 3 jagung betina tadi akan mengalami penyerbukan silang dari jalur jantan. ${ }^{32}$

Berdasarkan uraian tersebut di atas, beberapa yang dapat dicontohkan mengenai kasus yang berhubungan dengan HKI dimaksud, yaitu hak cipta, hak paten, hak merek, desain industri, rahasia dagang, desain tata letak sirkuit terpadu dan perlindungan varietas tanaman. Dalam penyelesaian permasalahan

dikarenakan masuk ke dalam sengketa bisnis, biasanya diselesaikan dengan jalur litigasi dan non litigasi. Litigasi merupakan jalur pengadilan, sedangkan non litigasi merupakan jalur arbitrase dan alternative penyelesaian sengketa.

Dalam kerangka hukum perjanjian berdasarkan buku III KUHPerdata dengan bersandar pada syarat syahnya perjanjian dan asasasas dalam hukum perjanjian, keseimbangan para pihak yang melakukan perjanjian lisensi yang dituangkan dalam suatu kontrak merupakan konsep dasar yang tidak dapat ditawar, mesti pada dasarnya para pihak mempunyai asas kebebasan berkontrak.

Kontrak lisensi yang dilatarbelakangi oleh adanya pengembangan bisnis secara internasional dan berada pada lintas negara di negara yang berbeda memang akan lebih praktis diseragamkan dengan perjanjian

\footnotetext{
${ }^{32} \mathrm{Pak}$ Tukirin : "Paten Benih seret Petani ke Pengadilan”, http://www. pergerakankebangsaan.org, diakses pada tanggal 20 Juli 2011.
} 
lisensi yang standart, asalkan isi dari perjanjian tersebut tidak bertentangan dengan ketentuan hukum yang mengaturnya, yaitu buku III KUHPerdata dan UU HKI secara umum. Sekalipun bersifat lintas negara, dalam hal ini pihak lisencor tidak dapat begitu saja membawa hukum negaranya untuk dituangkan dalam perjanjian lisensi yang ditawarkan kepada pihak lisencor, akan tetapi harus memperhatikan juga kepentingan keduabelah pihak antara lisencor dengan lisencee yaitu hak dan kewajiban sehingga ada pengertian yang sama diantara kedua belah pihak.

Dari adanya beberapa kasus yang terjadi terutama dalam penyelesaian gugatan pengadilan yang berhubungan dengan perjanjian ditujukan ke Pengadilan Negeri tempat perjanjian itu dilaksanakan, jika memang para pihak dalam klausula perjanjian menunjuk pada pilihan hukum dengan proses penyelesaian secara litigasi kecuali para pihak memilih sebaliknya. Hal tersebut diperbolehkan karena asas perjanjian menganut pacta sunt servanda. Dalam penentuan suatu pilihan hukum haruslah dilakukan secara patut dan tidak boleh bertentangan dengan ketentuan umum (yang bersifat memaksa), kesusilaan Akan tetapi jika dalam pemeriksaan ternyata ada unsur HKI nya dalam perjanjian yaitu perjanjian lisensi HKI yang berhubungan dengan hak cipta, paten, merek, desain industri, rahasia dagang, desain tata letak sirkuit terpadu dan perlindungan varietas tanaman maka kompetensi pengadilan niaga untuk memprosesnya.

Dalam kasus tertentu di bidang HKI seperti kasus hak cipta di atas, para pihak dapat saja membuat jenis perjanjian lisensi secara lisan sejauh tidak bertentangan dengan ketentuan undang-undang meski kekuatan hukumnya tidak sekuat secara tertulis, karena tetap masih dibolehkan dan syah menurut di hadapan syarat syahnya perjanjian.

Dalam kasus hak paten di atas, yang menjadi masalah hanya peraturan pemerintah mengenai perjanjian lisensi saja yang tak kunjung selesai sekalipun telah ada PP Nomor 27 tahun 2004 tentang tata cara pelaksanaan paten oleh pemerintah akan tetapi tidak memadai dan tepat 
sasaran dalam mengatur perjanjian lisensi. Di sisi yang lain, dalam semua perjanjian yang melibatkan unsur HKI harus dicatatkan dalam daftar di Direktorat Jenderal HKI sehingga dapat berlaku terhadap pihak ketiga, kemudian dilarang memuat ketentuan yang dapat menimbulkan akibat yang merugikan bagi perekonomian Indonesia atau memuat ketentuan yang mengakibatkan persaingan usaha tidak sehat sebagaimana diatur dalam perundang-undangan yang berlaku.

Ini berarti, perjanjian lisensi yang memuat ketentuan sebagaimana larangan di atas tidak dapat diberlakukan di Indonesia dan sebagai konsekuensinya maka Ditjen HKI wajib menolak untuk melakukan pencatatan perjanjian lisensi yang memuat hal tersebut, dengan memberitahukan alasannya kepada pemilik merek dan atau kuasanya.

Dalam perjanjian lisensi dikarenakan sifat baku-nya berpotensi membawa ketidakseimbangan para pihak (bargaining position), dimana licensee berada pada posisi yang lemah, misal terdapat klausul yang dapat memberatkan seperti : ketentuan yang mengharuskan licensee untuk membeli bahan baku dari licensor. Ketentuan semacam ini dapat menghambat perekonomian Indonesia. Ada pula ketentuan yang dapat menghambat kemampuan bangsa Indonesia dalam menguasai dan mengembangkan tekhnologi contohnya adalah dimuatnya ketentuan yang melarang licensee untuk melakukan perbaikan-perbaikan atas mutu-mutu barang. Dalam pasal 47 UUM misalnya, tidak diberikan klausaulaklausula apa saja yang terlarang untuk dimuat di dalam perjanjian lisensi merek sehingga tidak jelas klausula mana yang diperbolehkan dan klausula mana yang dilarang.

Masalah-masalah yang terjadi dalam upaya perlindungan hukum perjanjian lisensi hak kekayaan intelektual sebenarnya dapat diselesaikan melalui mekanisme hukum perjanjian itu sendiri oleh para pihak sehingga dapat memberikan jalan keluat terbaik demi terwujudnya hukum perjanjian yang saling menguntungkan diantara para pihak (win-win 
solution contract), di satu sisi memberikan kepastian hukum dan di sisi lain memberikan keadilan.

\section{PENUTUP}

Pengaturan mengenai ketentuan lisensi Hak Kekayaan Intelektual (HKI) di Indonesia diakomodir dalam semua pengaturan perundang-undangan Hak Kekayaan Intelektual meliputi Hak Cipta, Merek, Paten, Desain Tata Letak Sirkuit Terpadu, Desain Industri, Rahasia Dagang dan Perlindungan Varietas Tanaman. Dalam bagian pasal mengenai Lisensi dengan meletakan syaratsyarat dan amanat dibuatnya Peraturan Pemerintah dan Keputusan Presiden. Lisensi Hak Kekayaan Intelektual diwujudkan dalam bentuk perjanjian lisensi dan wajib diadakan pencatatan di Direktorat Jenderal HKI.

Hukum perjanjian memberikan perlindungan terhadap para pihak dalam praktek lisensi HKI di Indonesia dengan melihat pada 2 (dua) pengaturan baik dalam Undang-undang HKI itu sendiri dan Buku III Kitab Undang-Undang yang dituangkan dalam suatu perjanjian (kontrak), dikarenakan isi perjanjian mempunyai sifat baku maka pihak licensor dan licensee harus mematuhi isi perjanjian di samping juga harus memenuhi ketentuan yang telah diatur oleh UU HKI dan KUHPerdata. Sifat kepastian hukum dan keadilan juga menjadi titik perhatian dari pra sampai pasca perjanjian sehingga perjanjian benarbenar dapat mengakomodir kedua belah pihak.

\section{DAFTAR PUSTAKA}

August, Ray, Don Mayer dan Michael Bixny, 2009, International Business Law: Text, Cases, and Practice, Fifth Edition, Pearson Education International, London.

Badrulzaman, Mariam Darus, 1994, Aneka Hukum Bisnis, Alumni, Bandung.

Black, Henry Campbell, 1990, Black's Law Dictionary, ST.Paul.Minn:West Publishing Co.

Dratler Jay, Jr, 1994, Intellectual Property Rights : Commercial, Creative, and Industrial Property, Law Journal Seminars-Press 
Kartadjoemena, HS, 1996, GATT dan WTO : Sistem, Forum dan Lembaga Internasional di bidang perdagangan, Penerbit UI Press, Jakarta.

McKeough, Jill dan Stewart, Andrew, 1997, Intellectual Property in Australia, Butterworths, Australia.

Lubis, Andi Fahmi, dkk, 2009, Hukum Persaingan Usaha Antara Teks \& Konteks. Penerbit GTZ GmbH, Jerman.

Margono, Suyud dan Amir Angkasa, 2002, Komersialisasi Aset Intelektual, Penerbit PT Gramedia Widiasarana Indonesia, Jakarta.

Muhammad, Abdul Kadir, 1992, Hukum Perikatan, PT.Citra Aditya Bakti, Bandung.

Purba, Affrilyanna, dkk, 2005, TRIPs-WTO \& Hukum HKI Indonesia, Penerbit PT Rineka Cipta, Jakarta.

Putranti, Ika Riswanti, 2010, Lisensi Copyleft dan Perlindungan Open Source Software di Indonesia, Gallery Ilmu, Yogyakarta.

Subekti,1990, Hukum Perjanjian, PT.Intermasa, Jakarta.

Subekti, R dan R.Tjitrosudibio, 1992, Kitab Undang-undang Hukum Perdata. Pradnya Paramita, Jakarta.

White, Adward P, 1990, Licencing :A Strategy for Profits, NC KEW Licensing, Chaper Hill.

Widjaya, Gunawan, 2001, Waralaba. Rajawali Press, Jakarta.

Undang-undang Nomor 14 Tahun 2001 tentang Paten.

Undang-undang Nomor 15 Tahun 2001 tentang Merek.

Undang-undang Nomor 19 Tahun 2002 tentang Hak Cipta.

Undang-undang Nomor 29 Tahun 2000 tentang Perlindungan Varietas Tanaman.

Undang-undang Nomor 30 Tahun 2000 tentang Rahasia Dagang.

Undang-undang Nomor 31 Tentang Desain Industri.

Undang-undang Nomor 32 Tentang Desain Tata Letak Sirkuit Terpadu. 
Keputusan Menteri Hukum dan Perundang-undangan RI No. M.03.PR.07.10. Tahun 2000.

Hanim, Lutfiyah, "Akses atas ARV dan Perlindungan HKI", http://www.jothi.or.id.

Kasih, Juwita Aria, 2009, Perjanjian Lisensi terhadap Seluruh Karya Seni Berdasarkan Akta di Bawah Tangan Studi Kasus terhadap Perjanjian Lisensi Karya Seni Affandi, Thesis, Fakultas Hukum, Universitas Gadjah Mada, Yogyakarta.

“RPP Lisensi dan Lisensi Wajib Kembali Dibahas", http://www.Ristek.go.id.

Perjanjian Lisensi Cap Kaki Tiga Tetap Sah”, http://www.hukumonline.com.

Direktori Putusan Mahkamah Agung Republik Indonesia, http://www.putusan.mahkamah agung.go.id.

Paten Benih seret Petani ke Pengadilan", http://www. pergerakankebangsaan.org. 